\title{
Peranan Pemimpin Kristen Dalam Meningkatkan Kualitas Kerukunan Antar Umat Beragama Yang Pluralis
}

\author{
Gunar Sahari \\ Sekolah Tinggi Teologi Pelita Dunia Tangerang \\ gunar.sahari@gmail.com
}

\begin{abstract}
This study discusses the role of Christian leaders in improving the quality of harmony between pluralist religious communities. Researchers use qualitative methods or literature review to examine this topic. In conclusion, the researcher found that there are two factors that cause difficulty in creating religious harmony, namely: fanaticism and the spread of religion.
\end{abstract}

Keywords: Christian leader, harmony, pluralist.

Abstrak: Penelitian ini membahas tentang peranan pemimpin Kristen dalam meningkatkan kualitas kerukunan antar umat beragama yang pluralis. Peneliti menggunakan metode kualitatif atau kajian pustaka untuk meneliti topik ini. Pada kesimpulan peneliti menemukan bahwa ada dua faktor yang menyebabkan sulitnya terciptanya kerukunan beragama, yakni: fanatisme dan penyebarluasan agama.

Kata Kunci: Pemimpin Kristen, Kerukunan, Pluralis.

\section{Pendahuluan}

Pemimpin sebagai orang yang dapat menyebabkan orang lain melakukan apa yang mereka tidak ingin lakukan dan menjadikan mereka (pengikutnya) senang untuk melakukannya. ${ }^{1}$ Pemimpin yang sukses adalah pemimpin yang dapat mempengaruhi orang lain dan memiliki pengikut yang cukup besar. Sedangkan Tomatala mengatakan bahwa; Pemimpin Kristen adalah bagian dari pemimpin dunia akan tetapi pemimpin dunia bukanlah pemimpin Kristen. Hal ini ditunjukan dari pengertian pemimpin Kristen itu sendiri. Menurut Clinton

\footnotetext{
${ }^{1}$ Charles R Swindoll, Kepemimpinan yang Berhasil, (Surabaya : Yakin ,...), hlm.10
} 
"Pemimpin Kristen adalah seseorang yang telah dipanggil Allah sebagai pemimpin..."2. Pemimpin Kristen harus orang yang dipanggil oleh Allah dan memiliki kualifikasi yang terus bertumbuh dalam kepribadian dan karakter seperti Kristus. Oleh karena itu, pemimpin Kristen idealnya secara aktif bertumbuh dalam iman karena pengenalan akan Kristus.

Seorang pemimpin Kristen dikenal melalui tindakan dan model kepemimpinannya yang selalu berinisiatif, aktif dan inovatif dalam memimpin orang-orang yang dipemimpinnya. Adapun tindakan pemimpin Kristen adalah tindakannya dimotivasi oleh kasih dan bersedia khusus untuk melayani. ${ }^{3}$ Pemimpinan kristen adalah pelayan yang melayani dan bukan dilayani. Karena kasih Kristus, maka seorang pemimpin Kristen bersedia untuk menjadi pelayan atau melayani umat-Nya, sebagai implementasi Alkitab dan perintah Tuhan Yesus Kristus.

Alan E. Nelson mengatakan bahwa pemimpin Kristen mempunyai kuasa yang lebih besar dari pada pemimpin pada umumnya. ${ }^{4}$ Karena dirinya adalah orang pilihan yang dipersiapkan dan memberikan kuasa oleh Tuhan. Karena itu, pemimpin kristen yang demikian selalu melalui pembentukan-pembentukan dalam lembaga-lembaga kristen. Hasilnya akan menghasilkan pemimpin kristen melayani dan bukan dilayani, dan tidak memerintah dengan tangan besi dan penuh kuasa.

\section{Metode Penelitian}

Pada penelitian ini, penulis atau peneliti menggunakan pendekatan atau metode kualitatif untuk memperoleh data yang valid guna membangun sebuah teori yang berkaitan dengan tema atau pokok penelitian. Metode kualitatif yang dimaksud adalah mengkaji dan mengelaborasi setiap sumber, informasi dan data-data yang diperoleh dari pustaka.

\footnotetext{
2 Yakob Tomatala, Kepemimpinan Kristen, (Jakarta: YT Leadership Foundation, 2002), hlm.15-16

3 Tedw Engstron \& Edward R Dayton, Seni Manajemen bagi Pemimpin Kristen, (Bandung :Yayasan Kalam Hidup, 1998), hlm. 20

4 Alan E. Nelson, Spirituality \& Leadership, (Bandung: Yayasan Kalam Hidup, 2002), hlm.69
} 


\section{Hasil dan Pembahasan}

\section{Dasar Kepemimpinan}

Dasar kepemimpinan Kristen adalah karena pilihan dan panggilan Allah. Allah telah memanggilnya menjadi pemimpin, maka harus menyadarinya bahwa dirinya adalah seorang pemimpin yang dipilih dan panggil Allah untuk melayani Allah dan umatNya. Pemimpin Kristen adalah pemimpin yang dipanggil oleh Allah, untuk menjalankan tugas panggilan Allah berdasarkan Alkitab sebagai pedoman dalam kepemimpinannya.

Pemimpin Kristen mempunyai dasar yang tepat dalam memimpin, baik dalam hal bertindak, mengambil keputusan, dan menjalankan tugasnya. Dasar kepemimpinan Kristen adalah Kristus. ${ }^{5}$ Karena dipilih dan dipanggil Allah menjadi pemimpin, maka keteladanannya dalam menjalankan tugas kepemimpinannya adalah Tuhan Yesus Kristus yang adalah Allah yang berinkarnasi menjadi manusia.

S. H Sitohang mengatakan bahwa: Musa dikaruniai Tuhan sebagai salah seorang pemimpin terbesar dalam sejarah umat Israel sepanjang masa. Sebanyak kira-kira tiga juta jiwa umat Israel yang tegar tengkuk keluar dari perbudakan mesir dibawah pimpinannya menuju tanah Kanaan. Musa adalah pemimpin yang mempunyai hati sebagai hamba. Tuhan pun memujinya sebagai orang yang berhati lembut di dunia (Bilangan 12:3) dan mempunyai kasih yang teramat dalam terhadap bangsa Israel. ${ }^{6}$ Musa menjalankan tugas panggilan Allah dengan menjadi pemimpin yang bertanggungjawab atas mandat tersebut. Sebagai pemimpin yang dipilih dan dipanggil Allah, Musa menuntun umat pilihan Allah dengan penuh pengorbanan dan ketaatan karena hanya memandang dan mengandalkan Allah dalam tugas panggilannya sebagai pemimpin. Karena integritasnya dalam memimpin umat pilihan Allah, maka

${ }^{5}$ Sudomo, Ciri Utama Kepemimpinan Sejati

6 Samir H Sitohang, Kasus-kasus dalam Perjanjian Lama, (Bandung: Yayasan Kalam Hidup, 2005), hlm. 69 
Musa dijadikan sebagai figur dan model pemimpin Kristen sepanjang masa berdasarkan Alkitab.

Yakob Tomala mengatakan bahwa; Pemimpin Kristen harusnya memiliki model berpikir dasar yang Alkitabiah. Model berpikir yang Alkitabiah harus dibangun diatas model hidup serta ajaran Yesus Kristus dan diterapkan dalam diri. ${ }^{7}$ Pemimpin Kristen harus menjadikan Alkitab sebagai sumber dan pedoman hidupnya dalam menjalankan tugas kepemimpinan. Para pemimpin Kristen harus menjadikan Alkitab sebagai dasar ideal bagi idealisme kepemimpinan Kristen yang dipercayakan kepadanya. Secara ideal, pola kepemimpinan Kristus haruslah menjadi idealisme pemimpin Kristen. Adapun pola kepemimpinan Kristus untuk menjadi dasar kepemimpinan Kristen adalah pemimpin sebagai gembala, pemimpin sebagai hamba, pemimpin penatalayanan, dan pemimpin penuai. ${ }^{8}$ Pola dasar kepemimpinan pemimpin Kristen adalah pelayan yang melayani dan bukan dilayani, sebagai penerapan dari kepemimpinan dari pada Tuhan Yesus Kristus.

Jika diobservasi secara cermat, Alkitab tidak secara eksplisit menjelaskan definisi, pengertian atau penjelasan khusus tentang tema kepemimpinan Kristen. Namun, Alkitab secara jelas dan detail memaparkan tentang contohcontoh kepemimpinan dari pada orang-orang pilihan Allah di Perjanjian Lama maupun Perjanjian baru yang dapat dijadikan sebagai model dan contoh bagi para pemimpin Kristen sepanjang masa memimpin umat Allah. Memahami fakta, model dan contoh-contoh kepemimpinan para tokoh dalam Alkitab, maka secara menyeluruh didapati pokok kepemimpinan dengan menjelaskan tentang konsep, defenisi dan model kepemimpinan kristen terdapat di dalam Alkitab.

Pemimpin Kristen harus menguasai Alkitab dan dapat menjadi memonitor pengajaran yang dilaksanakan dalam tubuh (umat-Nya). ${ }^{9}$ Dalam melaksanakan tugasnya, dan mengambil keputusan, seorang pemimpin kristen

\footnotetext{
7 Yakob Tomatala, Kepemimpinan Yang Dinamis, (Jakarta: YT Leadershioo Foundation, 1997), hlm. 61

8 Ibid, hlm.61

${ }_{9}^{9}$ Mark Atteberry, 10 Hal Terbodoh yang Dilakukan Orang Kristen, (Jakarta: Gloria Usaha Mulia, 2009), hlm. 188
} 
mesti menerapkan dan menggunakan prinsip-prinsip yang terdapat di Alkitab. Seorang pemimpin Kristen perlu memastikan apakah telah melaksanakan tugasnya sesuai Alkitab. Karena itu, Alkitab harus dijadikan oleh setiap pemimpin Kristen sebagai rujukan, tuntunan dan pedoman dalam menjalankan tugas panggilannya. Pemimpin Kristen yang bertanggung jawab atas panggilannya, selalu menjadikan Alkitab sebagai panduan dan standar hidupnya.

\section{Ciri-ciri Pemimpin Kristen}

Ciri-ciri pemimpin Kristen yang bersumber dari Alkitab dan meneladani Tuhan Yesus Kristus sebagai berikut:

\section{a. Pertobatan}

Syarat utama seeorang pemimpin kristen adalah pertobatan atau lahir baru yaitu meninggalkan kehidupan dosa dan berpaling kepada kehidupan Tuhan Yesus Kristus. Pertobatan atau lahir baru adalah sarana kasih karunia Tuhan di mana Roh Kudus menyadarkan orang akan kejahatan dosanya dan dimana orang yang beriman kepada Kristus merendahkan diri karena dosanya. Seorang pemimpin kristen harus mengalami kelahiran baru atau pertobatan, dan terus diproses sampai menjadi serupa dengan Tuhan Yesus Kristus. Karena standar kepemimpinannya dalam memimpin umat Tuhan adalah Alkitab dan meneladani hidup dan kepemimpinan Tuhan Yesus Kristus.

Louis Berkhof mengatakan bahwa lahir baru terjadinya perubahan radikal dari sikap hati yang ada di bawah kuasa Roh Kudus sehingga melahirkan sebuah kehidupan yang menggerakan ke arah Allah. ${ }^{10}$ Proses pertobatan atau lahir barunya seorang pemimpin Kristen terjadi karena ada peran Roh Kudus yang menggerakan dan menuntunnya untuk megambil keputusan agar 
meninggalkan kehidupan dosa dan menyerahkan hidupnya kepada Tuhan Yesus Kristus.

Selanjutnya Kline mengatakan bahwa; Lahir baru adalah suatu perubahan menyeluruh secara terpadu dan dinamis. ${ }^{11}$ Peristiwa pertobatan atau kelahiran baru seorang pemimpin Kristen, merupakan proses perubahan ini mempengaruhi seluruh eksistensi kehidupannya yang berdampak bagi hubungannya dengan Tuhan maupun hubungannya dengan sesamanya. Peristiwa pertobatan merupakan pengalaman hidup yang dikehendaki Allah didalam kehidupan orang percaya. Karena Allah adalah kudus adanya dan manusia telah berdosa karena pelanggarannya, maka tanpa pertobatan manusia tidak berkenan kepada Allah. Dengan demikian, maka menurut Gottfried OseiMensah bahwa; Syarat pertama untuk menjadi pemimpin Kristen adalah telah bertobat (dapat diartikan dengan lahir baru) dengan sungguh-sungguh. ${ }^{12}$ Pemimpin Kristen adalah orang yang di panggil Allah untuk berperan menggantikan Allah memimpin umat Allah. Pemimpin kristen yang dipilih dan dipanggil Allah untuk memimpin, membimbing dan mengembalakan umat Allah adalah pemimpin yang sudah lahir baru. Akibatnya jika pemimpin Kristen tidak bertobat ini akan berdampak buruk bagi kesatuan gereja, kerukunan pemimpin Agama, maupun kerukunan umat beragama. Adapaun dampak buruknya ialah pemimpin kristen yang tidak bertobat, tidak akan mengerti arti melayani orang lain, bahkan ingin dilayani.

\section{b. Karakter Pemimpin Kristen}

Mengenai karaketr pemimpin Kristen, maka Franz Magnis Suseno mengatakan bahwa; Etika adalah suatu sikap dan perilaku yang menunjukan kesediaan dan kesanggupan seorang secara sadar untuk mencapai ketentuan

11 M.R. Kline, ensklopedi alkitab masa kini I, (Jakarta: yayasan komunikasi bina kasih, 1992), hlm 629

12 Gottfried Osei-Mensah, Dicari Pemimpin yang Menjadi Pelayan, (Jakarta : Yayasan Komunikasi Bina Kasih, 2002), hlm. 34 
dan norma yang berlaku dalam kelompok masyarakat atau organisasi. ${ }^{13}$ Seorang pemimpin kristen, harus memahami karakter dalam kehidupan kristen yang standarnya kehidupan Tuhan Yesus Kristus. Hal ini erat korelasinya dengan etika dan karakter karena setiap gaya hidup dan kebijakan pemimpin mengandung pertimbangan dan keputusan etis yang berkaitan langsung dengan sistem nilai manusia, mendorong tumbuhnya naluri moralitas, untuk melakukan pilihan-pilihan yang baik dan benar demi kepentingan umum.

J. Verkuyl menjelaskan bahwa; Adapun pola etika jika dipandang dari sudut kepercayaan kepada Alkitab adalah segala yang dikehendaki Allah, itulah yang baik. ${ }^{14}$ Landasan etika dan karakter seorang pemimpin kristen adalah Alkitab. Hal ini berarti mentaati aturan, perintah, dan tatanan hidup sebagai pemimpin kristen adalah Alkitab. Etika dan karakter kristen merupakan hal terpenting yang perlu diketahui oleh para pemimpin Kristen. Karakter memang diperlukan akan tetapi tidak boleh bertindak sebagai Allah. Di dalam lingkungan bermasyarakat pemimpin dituntut untuk menjaga citra diri melalui kinerja dan prilaku dalam menjalankan tugasnya dengan menghindari diri dari perbuatan yang tercela yang dapat merugikan diri sendiri dan orang lain. Norma etika merupakan keperluan yang berkaitan dengan prilaku manusia yang menyangkut nilai luhur dalam bertindak bagi kehidupan seorang.

Dalam melaksanakan tugas kepemimpinan, pemimpin perlu memperhatikan etika dan karakter kepemimpinan, adapun yang menjadi dasar sumber mutlak dari pengetahuan adalah Alkitab. Adapun karakter dan etika kepemimpinan bersumber pada paham-paham dasar mengenai kepemimpinan tersebut. Yakob Tomatala mengatakan, kepemimpinan Kristen memiliki dasar yang Alkitabiah, yang berkenaan dengan "Inkarnasi Yesus Kristus"15 Pemimpin Kristen dapat menjadi teladan bagi pengikutnya, asal memahami tentang

\footnotetext{
13Franz Magnis Suseno, Etika Dasar;Masalah-Masalah Pokok Filsafat Moral, (Yogyakarta: Kanisius, 1987), hlm.18

14J. Verkuyl . Etika Kristen, (Jakarta : BPK Gunung Mulia), hlm, 3

15Yakokb Tomatala, Kepemimpinan Yang Dinamis, (Jakarta: YT Leadership Foundation, 1997) , hlm. 49
} 
beretika dengan anggota jemaatnya baik dalam perkataan maupun dalam perbutannya sehari-hari.

\section{Kerukunan Antar Umat Beragama}

Bangsa Indonesia adalah bangsa yang plural termasuk dalam hal beragama. Karena itu, dalam menjalani kehidupan berbangsa dan bernegara para pemimpin hendaknya menciptakan kerukunan antar umat beragama di Indonesia.

\section{Definisi Kerukunan Antar Umat Beragama.}

Mengenai kerukunan antar umat beragama Ricki Mudjiono dan FX. Dicki P., mendefenisikan bahwa; Kerukunan berasal dari kata rukun yang artinya dapat berdampingan, damai, dan bersepakat, jadi kerukunan artinya kesepakatan, kekompakan dan rasa rukun. ${ }^{16}$ Hidup rukun merupakan dambaan dari para pendiri bangsa Indonesia dengan semboyan "Bhineka Tunggal Ika” artinya berbeda-beda, tetapi tetap satu jua. Dengan demikian, maka kerukunan hidup antar umat beragama berarti tidak adanya perbedaan antar umat beragama di Indonesia sebagai faktor yang pemecah belah dalam kehidupan bermasyarakat karena perbedaan agama atau kepercayaan. Jika dipahami dengan seksama, maka peranan dari para pemimpin agama adalah memahami bahwa perbedaan memang tak dapat disatukan tetapi dapat dikelolah menjadi suatu keindahan dan kekuatan dalam membangun bangsa Indonesia. Umat beragama adalah para penganut atau pengingkut suatu kepercayaan, yang harus berperan para pemimpin agama dalam menciptakan kerukunan. Karena berdasarkan makna kata "rukun" maka kerukunan umat beragama adalah kekompakan umat beragam atau hidup damai dalam menjalankan suatu kepercayannya masing-masing, namun tetap bersatu dalam membangun bangsa Indonesia.

16Ricki Mudjiono dan FX. Dicki P, Kamus Umum Bahasa Indonesia, ( Jakarta: Scientific Prees, 2008), hlm. 472 
Pengertian kerukunan antar hidup umat beragama yang diatur dalam Peraturan Bersama dua menteri yaitu; Menteri Agama dan Menteri Dalam Negeri No: 9 Tahun 2006 dan No : 8 Tahun 2006 tentang kerukunan umat beragama, adalah: Kerukunan antar umat beragama adalah keadaan hubungan sesama umat beragama yang dilandasi toleransi, saling pengertian, saling menghormati, menghargai kesetaraan dalam pengamalan ajaran agamanya dan kerjasama dalam kehidupan bermasyarakat, berbangsa dan bernegara di dalam Negara Kesatuan Republik Indonesia berdasarkan Pancasila dan UndangUndang Dasar Negara Republik Indonesia tahun 1945.17 Selanjutnya arti kerukunan dalam Peraturan Bersama Menteri Agama dan Menteri Dalam Negeri No: 9 Tahun 2006 dan No: 8 Tahun 2006. Perspektif ini memberikan pemahaman tentang kesetaraan kedudukan antar umat beragama di Indonesia. Selanjutnya para pemimpin agama berkewajiban dan harus proaktif dalam membangun pemahaman dan sikap kerukunan antar umat beragama mulai dari umat di agama yang dipimpinnya

\section{Dasar Kerukunan Antar Umat Beragama}

Dasar hukum kerukunan antar umat beragama di Indonesia ialah Pancasila dan Undang-Undang Dasar 1945 pasal 29; (1). Negara berdasarkan atas Ketuhanan Yang Maha esa. (2). Negara menjamin kemerdekaan tiap-tiap penduduk untuk memeluk agamanya masing-masing dan untuk beribadat menurut agam dan kepercayaanya itu.

Di Indonesia mengakui 6 agama negara yaitu (1). Agama Islam; (2). Agama Kristen Protestan; (3). Agama Kristen Katolik; (4). Agama Budha; (5). Agama Hindu; dan (6). Agama Khongucu. Pluralisme beragama ini jika dikelolah dengan baik dapat menjadi berkat, tapi jika tidak dapat dikelolah dengan baik dapat menjadi musibah bagi bangsa Indonesia. Oleh karena itu, diperlukan

\footnotetext{
17 Peraturan Bersama Menteri Agama dan Menteri Dalam Negeri No: 9 Tahun 2006 dan No : 8 Tahun 2006
} 
kesadaran antar para pemimpin umat beragama agar dapat mengelolah dan menjaga kelestarian dan kontinuitas kehidupan beragama di Indonesia.

Kerukunan antar umat beragama di Indonesia dapat jadikan kekuatan untuk mencapai cita-cita kemerdekaan Indonesia. Presiden Soekarno menyadari akan kekuatan hidup kerukunan antar umat beragama, menyatakan bahwa: Pertama-tama kita harus menyadari bahwa masyarakat Indonesia adalah masyarakat yang majemuk. Juga dalam hal keagamaan karena itu semuanya hendaknya senantiasa bertenggang rasa satu sama lain. Kita harus meghormati keyakinan orang lain, walaupun kita tidak setuju, sebagaiman kita juga menginginkan orang lain menghormati keyakinan kita. Hal ini berlaku tidak hanya dalam perbedaan agama, akan tetapi juga dalam hal perbedaan paham dan aliran agama itu memang merupakan kenyataan yang terdapat dalam semua agama. ${ }^{18}$ Para pemimpin bangsa harus memahami maksud dan tujuan dari ungkapan Presiden Soekarno, dengan melanjutkan tongkat estafet kepemimpinan bangsa Indonesia bersama para pemimpin antara umat beragama, dengan terus berupaya agar dapat menjaga dan menciptakan kerukunan hidup beragama secara baik. Para pemimpin Umat beragama di Indonesia hendaknya dapat membangun setiap umat yang dipimpinnya dengan membangun pemahaman yang benar tentang kerukunan hidup umat beragama dengan hidup saling menghargai, menghormati, bertenggang rasa, dan toleransi terhadap agama lain sebagai saudara sebangsa dan se-tanah air yang berbeda keyakinannya. Pemahaman paling mendasar yang harus dibangun dalam kehidupan umat beragama adalah semua umat beragama di Indonesia sama kedudukan, pangkat, kekuasaan, kekayaan dan lain-lain karena dimata Tuhan semua manusia adalah mahluk yang sama dan sederajat.

Nur Alim Wahyudi menyatakan, "Kalau agama disuruh rukun tidak bisa, sumber-sumber (ajarannya) dan tatacara (ibadah) saja berbeda-beda. Tetapi umatnya kan bisa disuruh rukun".19 Pemahaman yang benar tentang kerukunan

\footnotetext{
18 Ibid. hlm, 78

19http://umum.kompasiana.com/2009/09/12/agama-disuruh-rukun-ya-tidak-bisatapi-umatnya-bisa/
} 
hidup beragama adalah umat antar agama yang harus hidup rukun dengan saling menerima satu dengan yang lainnya dalam perbedaan keyakinan dan bukan agama yang harus hidup rukun. Perbedaan paham, dogma dan pandangan hidup tiap-tiap agama makin menambah kemajamukan di negara Indonesia. Karena kemajuemukan Negara Kesatuan Republik Indonesia tidak hanya agama, tetapi kemajemukan suku, ras, etnis, bahasa, budaya dan lain-lain. Untuk itu, maka dibutuhkan alat atau sarana yang kuat dan kokoh agar dapat menciptakan kerukunan antara kemajemukan sebagai persatuan tiap-tiap warga negaranya. Alat dan metode atau strategi yang dimaksud untuk menciptakan kerukunan diantara kemajemukan bangsa. Alat dan metode atau strategi dibutuhkan telah dibangun dengan kokoh oleh para pendiri bangsa Indoesia, yaitu; (1). Sumpah pemuda; (2). Bhineka Tunggal Ika; (3). Pancasila; dan (4). UUD 45 sebagai pengikat yang mempersatukan seluruh bangsa Indonesia dari sabang sampai Merauke.

Y. B. Mangunwijaya berpendapat bahwa "yang menyatukan masyarakat Indonesia dalam dimensi tertinggi dan terdalam adalah keiman dan ketaqwaan kepada Tuhan Yang Maha Esa"20. Pernyataan ini dilengkapi oleh sila kemanusiaan yang adil dan beradab. Wujud dari kepercayaan kepada Tuhan Yang Maha Esa adalah memiliki hubungan yang baik secara vertical dan horizontal. Ini dihayati dan diamalkan secara konsekuen dan kosisten maka buahnya ialah persahabatan, persaudaraan, saling menghormati. Persatuan dalam artiannya bukanlah tidak terjadinya konflik, tetapi jika terjadi konflik atau berselisih, keinginan selalu ingin rukun kembali besar.

Menurut Zuly Qodir, Agama adalah pembawa damai.21 Karena agama adalah pembawa damai, maka kerukunan terbukti tercipta di Indonesia sebagai bangsa yang beragama yang dapat mengamalkan nilai-nilai keagamaan. Kerukunan sangatlah penting di negara ini, jika tidak disadari bahwa pentingnya

20 Y. B. Mangunwijaya, Pluralitas Agama; Kerukunan dalam Keberagaman, (Jakarta : Gramedia, 2001), hlm.31

21 Zuly Qodir, ibid. hlm, 36 
kerukunan maka negara ini akan menjadi negara yang tertinggal. Bukalah mata, bukalah hati, lihat fakta dan lihatlah bukti bahwa kerukunan itu sangatlah penting dalam berbangsa dan bernegara di Indonesia.

\section{Jenis-jenis kerukunan}

\section{a. Kerukunan intern umat beragama}

Kemajemukan tidak hanya ada dalam agama, tetapi juga dalam agama itu sendiri juga memiliki kemajemukan. Adapun kemajemukan di dalam kekristenan ialah Ortodoks, Khatolik Roma, berbagai denominasi dalam Protestan dan Pentakosta, dengan berbagai bentuk organisasi gerejanya. Adapun perbedaan itu disebabkan pada beraneragam dalam penafsiran dan penerapan iman. ${ }^{22}$ Didalam internal setiap agama terdapat perbedaan dalam pemahaman karena penafsiran dalam agama tersebut. Hal ini terjadi karena upaya dalam tafsiran oleh setiap pemimpin agama, karena memiliki pemahaman atau penekanan yang berbeda.

Chandra Suwondo mengatakan bahwa: Perlu diakui bahwa kekristenan memiliki kemajemukan sehingga semestinya pemimpin-pemimpin Kristen perlu menghormati perbedaan. Dengan menghormati perbedaan pemimpin akan semakin membuka potensi pikirannya dan berpikir kritis, akan tetapi bila menunjukan sikap tidak meghormati maka semakin tertutup dengan perbedaan itu berarti menutup potensi pikiran ${ }^{23}$. Antar para pemimpin kristen juga harus menghargai karena perbedaan pemahaman atau penafsiran didalam agama Kristen. Pemimpin Kristen adalah pemimpin yang meneladani Kristus, akan tetapi akan menjadi bahaya bila pemimpin kristen belum memenuhi kareteria pemimpin Kristen karena itu dapat menyebabkan perpecahan. Foktor perpecahan dikalangan Kristen adalah pemimpin yang belum bertobat yang hlm.23-24

22 Wesley Ariarajah, Tak Mungkin Tanpa Sesamaku, (Jakarta: BPK Gunung Mulia, 2008),

${ }^{23}$ Chandra Suwondo, Sikap Positif, (Jakarta, Metanoia, 2005), hlm. 10-11 
ingin membangun kerajaan sendiri. ${ }^{24}$ Perpecahan dapat terjadi jika pemimpinnya tidak mengerti tentang kehendak Allah. Karena itu pemimpin kristen harus memahami kehendak Allah dan saling menghormati antar para pemimpin kristen didalam agama kristen.

Mark Atteberry menjelaskan bahwa; Perebutan jemaat, saling menghina dan terhambatnya pelayanan adalah akibat dari perpecahan. Adapun akibatnya bagi jemaat adalah jutaan orang telah menderita luka rohani yang mendalam dan terkadang fatal dalam tubuh Kristus. ${ }^{25}$ Para pemimpin gereja harus melihat perbedaan didalam pelayanan gereja Tuhan sebagai anggota tubuh Kristus yang saling melengkapi, sehingga perbedaan tidak menjadi masalah konflik tetapi menjadi kekuatan karena saling melengkapi. Perbedaan memang tidak dapat dihindari tertapi perpecahan seperti ini bukanlah tujuan ataupun dikehendaki Allah, maka persatuan perlu di ciptakan.

Menurut H. Abdul Fatah yang mengatakan bahwa; kelompok-kelompok dan pemimpin umat belum bisa diandalkan untuk membangun sebuah kerukunannya sendiri. ${ }^{26}$ Karena terakadang para pemimpin intern agama tertentu yang menjadi pemicu terjadi konflik intern agama. Jadi kerukunan antar umat beragama dapat terwujud, jika dimulai dari para pemimpin umat beragama, menciptakan kerukunan dari dirinya sendiri.

Natan Setia Budi dan Thresia Kristanty menjelaskan bahwa; Kemajemukan dalam kekristenan perlu menyadari bahwa sebagai satu tubuh perlu pesatuan. Tidak ada yang besar ataupun yang kecil walaupun berbedabeda dalam karunia yang diberi Allah. Hendaknya dapat hidup damai satu sama lain (1 Tesalonika 5:13). Kesatuan dalam kekristenan perlu baik itu untuk umat itu sendiri maupun untuk umat lain. Hal ini supaya Kristus mau hadir, tinggal

24 Gottfried Osei-Mensah, Dicari Pemimpin yang Menjadi Pelayan, (Jakarta:Yayasan Komunikasi Bina Kasih, 2002), hlm.37

25 Mark Atteberry, 10 Hal Terbodoh yang Dilakukan Orang Kristen, (Jakarta: Gloria Usaha Mulia, 2009), hlm.176

${ }^{26}$ H. Abdul Fatah, Rukun, (Jakarta: Pusat Kerukunan UmatBeragama Sekertariat Jenderal Departemen Agama R.I), hlm. 20 
dan menyatakan kuasa-Nya. ${ }^{27}$ Kerukunan antar umat beragama akan tercipta jika, terjadi kerukunan intern umat beragama. Perbedaan praktek keyakinan dalam satu agama, seharusnya tidak menjadi pemicu yang memperlihatkan kepada antar agama bahwa ada perbedaan diintern agama yang lain.

\section{b. Kerukunan antar umat Beragama}

Dalam kerukunan antar umat beragama, maka umat kristen di Indonesia ada bersama-sama umat dari agama Islam, agama Kristen Khatolik, agama Budha, agama Hindu, dan agama Khonghucu sebagai umat beragama yang majemuk. Setiap agama mempunyai ajaran dan ritual kepercayaannya masingmasing yang berbeda dan bahkan sebagian saling bertentangan pada bagianbagian tertentu. Paul J. Griffths mengatakana bahwa; Ada banyak perbedaan besar dalam agama namun perlu untuk dihormati, bukanhanya karena alasanalasan politis atau sekedar rasa hormat, melainkan dengan tulus hati. ${ }^{28}$ Perbedaan-perbedaan dalam agama yang perlu dihormati adalah perbedaan ajaran, perbedaan sikap, perbedaan penyembahan, perbedaan-perbedaan ritual lainnya. Namun, saling menghormati antar agama dalam menjalankan tuntutan agamanya merupakan cara yang paling ideal dalam menjaga kerukunan dalam keberagaman beragama di Indonesia.

Menurut A. N. Wilson bahwa “Cinta Tuhan adalah akar dari kejahatan”.29 Artinya sangat sulit untuk menciptakan kerukunan hidup antar umat beragama. Jika umat beragama sulit dalam menciptakan kerukunan, berarti mencintai Tuhan merupakan akar dari perpecahan. Padahal dasar utama dari setiap agama adalah memberikan ketenteraman. Maka selanjutnya Wilson mengatakan; Jika agama tidak bisa mendidik orang untuk mencapai tujuan-tujuan kedamaian dan

27 Natan Setia Budi dan Thresia Kristanty, Bergereja dan Beroikumene di Era Reformasi,(Jakarta : Suara GKYE Pedulil Bangsa, 2002), hlm.125

28 Paul J. Griffths, Kekristenan di Mata Orang Bukan Kristen, (Jakarta: BPK Gunung Mulia, 2008), hlm.294

${ }^{29}$ A. N. Wilson, dikutif oleh Nurcholis Mazid, Islam Agama Kemanusiaan : Membangun Tradisi Dan Misi Baru Islam Indonesia, (Jakarta, Paramadina, 1995), hlm. 53 
cinta kasih, lantas apakah tujuan kehadiran agama bagi manusia? ${ }^{30}$ Pernyataan ini perlu direnungkan oleh setiap pemimpin agama, tentang tujuan beragama bagi manusia. Karena konflik yang terjadi antar umat beragama, sangat mempengaruhi hakekat agama itu sendiri bagi para penganutnya. Jika umat beragama mencintai Tuhan, tapi menciptakan konflik, maka tidak salah jika ada pihak-pihak yang menganggap bahwa akar dari terjadinya perang adalah agama.

\section{Kesimpulan}

Adapun faktor-faktor penghambat kerukunan antar umat beragama di Indonesia dapat dibahas sebagai berikut:

\section{a. Fanatisme}

Fanatisme ${ }^{31}$ dari kata fanatis yang berarti keyakinan (kepercayaan) yang terlalu kuat terhadap ajaran (politik, agama, dan sebagainya). Fanatisme agama berarti menganggap agamanya yang paling benar dan mengangap agama lain salah. Sikap ini merupakan wujud dari sikap fanatisme yang sempit. Jelas fanatik yang sempit merupakan bahaya bagi terciptanya kerukunan antar umat beragama. Mengenai fanatisme agama dalam agama Islam maka Reyhan Hakim mengutip ayat Al-Quran surat Al-jumu'ah : 6, yang mengatakan: 'hai orangorang penganut agama yahudi jika kamu mendakwakan bahwa sesungguhnya kamu sajalah kekasih Allah bukan manusia-manusia yang lain, maka harapkanlah kematian mu, jika kamu adalah orang-orang benar. ${ }^{32}$ Jika penekanan ayat ini merupakan sikap fanatisme penganut agama Yahudi, sebagai satu-satunya agama yang penganutnya adalah kekasih Allah, maka sikap tersebut dapat memunculkan konflik dan berbahaya terhadap perwujudan kerukunan.

30 Ibid, hlm. 53

31 Fanatisme berati keyakinan (kepercayaan) yang terlalu kuat terhadap ajaran (politik, agama, dan sebagainya)

32 Reyhan Hakim, Sialan Beckham Ternyata Yahudi, (Jakarta: Suka Buku, 2009), hlm. 4 
Y. B. Mangunwijaya menjelaskan bahwa; Dalam masyarakat yang multikultural dan beragam, orang-orang mengklaim bahwa semua agama benar dan setiap agama mempunyai kitab yang benar. ${ }^{33}$ Pernyataan ini melihat semua agama sama-sama menyembah Tuhan Yang Maha Esa. Namun, setiap agama mempunyai ajaran dan ritualnya masing-masing dalam menyembah Allah. Norman Geisler mengatakan bahwa; Tidak mungkin semuanya benar, dia menbandingkan Al-Quran menyatakan bahwa Yesus tidak bangkit (An Nisaa 157). Sedangkan dalam Alkitab yang mengatakan bahwa Yesus mati dan bangkit pada hari yang ketiga. ${ }^{34}$ Jika diselidiki didalam kitab suci masing-masing agama (Al-quran dan Alkitab) maka akan ditemukan perbedaan yang jelas dari kedua pendapat tersebut, karena setiap agama mempunyai landasan kebenaran. Fred Smith, SR mengatakan bahwa: Kebenaran tidak terdapat kesalahan, tetapi kesalahan dapat berisi kebenaran. ${ }^{35}$ Semua agama menyakini bahwa ajaran agamanya adalah kebenaran, maka setiap kebenaran yang diyakininya tidak mungkin sebagai kesalahan. Karena itu, akan menjadi konflik jika agama lain melihat kebenaran agama lain sebagai kesalahan dari pandangan agamanya. Sebaliknya kesalahan dapat menjadi kebenaran karena kebenaran dapat dipelajari dari suatu kesalahan untuk diperbaikinya menjadi kebenaran.

Norman Geisler menjelaskan bahwa; Kekristenan tidak mengklaim bahwa tidak ada kebenaran didalam agama-agama lain. Kristen menyatakan bahwa agama Kristen adalah benar. ${ }^{36}$ Dalam pemahaman bahwa ada banyak hal-hal yang benar dan baik menurut ajaran agama-agama lain, namun jika kebenaran itu bertentangan dengan ajaran Alkitab, maka itu salah. Karena landasan kebenaran dalam agama Kristen adalah Alkitab yang inti beritanya adalah Yesus Kristus dan bergantung pada Roh Kudus.

33 Y. B. Mangunwijaya, Pluralitas Agama; Kerukunan dalam Keberagaman, (Jakarta : Gramedia, 2001), hlm.1

${ }^{34}$ Norman Geisler, Who Made God ( Siapakah Yang Membuat Allah?), (Bandung: Pioner Jaya, 2009), hlm. 153

35 Fred Smith, SR, Memimpin dengan Integritas, (Jakarta: Yayasan Pekabaran Injil Immanuel, 2002), hlm.127

36Norman Geisler, Who Made God ( Siapakah Yang Membuat Allah?), (Bandung: Pioner Jaya, 2009), hlm. 156 


\section{b. Penyebarluasan agama}

Mengenai penyebarluasan masing agama, maka S. Wesley Ariarajah mengatakan bahwa "semua agama (kecuali yang di sebut agama-agama tradisonal atau kepercayaan) pada umumnya bersifat misioner".37 Dalam pengertian bahwa setiap agama modern ingin menyebarluaskan agamanya. Jadi perdebatan mengenai masalah misi merupakan perdebatan semua agama modern, karena semua agama modern ingin menyebarluaskan agama dan ajarannya.

Upaya masing-masing agama dalam menyebarluaskan agamanya, kemudian menimbulkan adanya asumsi sampai terjadi perselisihan antara umat beragama tentang penyiaran agama. Sebenarnya perselisihan tersebut tidak akan terjadi jika para pemimin agama menyadari bahwa semua agama modern memiliki sifat missioner. Karena itu, menurtut S. Wesley Ariarajah bahwa: "Penyiaran agama bukanlah merupakan suatu masalah".38 Karena yang menimbulkan perselisihan dan pepecahan ialah adanya kecurigaan antar pemimpin dan umat beragama, karena sama-sama adalah agama yang bersifat missioner. Schumann menjelaskan bahwa; Permasalahan misi ini juga pernah di bawah dalam pertemuan. ${ }^{39}$ Dengan demikian, maka antar pemimpin dan umat beragama harus mencari dan menemukan suatu kode etik berdasarkan sikap jujur terhadap diri sendiri maupun terhadap pihak lain, dalam melakuakan penyiaran agama itu.

Menurut H. M. Zainuddin Daulay bahwa; Masuknya anggota partai komunis menimbulkan kecemburuan dari kelomok Islam yang diikuti dengan kemarahan umat Islam terhadap kegiatan umat Kristen dan khatolik yang dianggap telah menarik mereka masuk ke agama Kristen dan Khatolik dengan

37 S. Wesley Ariarajah, Tak Mungkin Tanpa Sesamaku, (Jakarta: BPK Gunung Mulia, 2008), hlm. 107

38 S. Wesley Ariarajah hal. Tak Mungkin Tanpa Sesamaku, (Jakarta: BPK Gunung Mulia, 2008), hlm.108

${ }^{39}$ H Schumann, Dialog Antar Umat Beragama, (Jakarta: Gunung mulia, 2008), hlm. 98 
bujukan materi dengan demikian maka umat Islam telah terjadi usaha kristennisasi terhadap umat Islam secara besar-besaran. ${ }^{40}$ Pernyataan ini terindikasi bahwa konflik yang berhubugan dengan Partai komunis Indonesia (PKI) oleh pihak militer, ada kaitannya dengan penyebarluasan agama di Indonesia. Orang-orang bekas anggota G 30 S/PKI yang ingin menyelamatkan diri masuk ke kelompok-kelompok agama yang ada di Indonesia dan terjadilah gelombang besar masuknya anggota partai komunis tersebut ke dalam agama Kristen dan Khatolik.

Menurut Dr. Ibrohim menjelaskan bahwa dalam pertemuan Kristen-Islam di Chambesi pada juni 1967 menyatakan: Umat Kristen akan tetap meneruskan usaha untuk menyiarkan agamanya di antara umat Islam, karena itulah keyakinannya, walaupun dihalangi oleh kekuatan lahiriah tanpa mengindahkan umat Islam dan pengikut agama-agama lainnya yang jumlahnya lebih dari 95\% dari rakyat indonesia". ${ }^{41}$ Pernyaatan di atas membuktikan bahwa penyiaran tentang Yesus Kristus adalah Tuhan dan Juruselamat umat manusia dan satusatunya jalan kebenaran dan hidup, merupakan mandat yang wajib diberitakan sampai keujung-ujung bumi oleh setiap orang kristen atau pengikut kristus (Matius 28:18-20). Umat kristen harus menjaga kerukunan hidup beragama Indonesia, tapi juga sudah menjadi kewajiban untuk memberitakan Injil dan menjadikan semua bangsa menjadi murid Tuhan Yesus Kristus tanpa menkristenkan agama lain.

\section{Referensi}

Charles R Swindoll, Kepemimpinan yang Berhasil, Surabaya : Yakin ,...

Yakob Tomatala, Kepemimpinan Kristen, Jakarta: YT Leadership Foundation, 2002.

------------, Kepemimpinan Yang Dinamis, Jakarta: YT Leadershioo Foundation, 1997

Tedw Engstron \& Edward R Dayton, Seni Manajemen bagi Pemimpin Kristen, Bandung :Yayasan Kalam Hidup, 1998

${ }^{40}$ H.M.Zainuddin Daulay, Rukun, (Jakarta: Pusat Kerukunan UmatBeragama Sekertariat Jenderal Departemen Agama R.I), hlm 17

41 Ibrohim dikutip oleh Olaf H Schumann, Dialog Antar Umat Beragama, (Jakarta: Gunung Mulia, 2008), hlm. 98 
Alan E. Nelson, Spirituality \& Leadership, Bandung: Yayasan Kalam Hidup, 2002

Samir H Sitohang, Kasus-kasus dalam Perjanjian Lama, Bandung: Yayasan Kalam Hidup, 2005

Mark Atteberry, 10 Hal Terbodah yang Dilakukan Orang Kristen, Jakarta: Gloria Usaha Mulia, 2009

Pengakuan Iman Baptis 1689, Carey Publication 1996

Luis Berkhof, Teologi Sistematika Doktrin Keselamatan, Jakarta: Momentum, 2004

M.R. Kline, ensklopedi alkitab masa kini I, Jakarta: yayasan komunikasi bina kasih, 1992

Gottfried Osei-Mensah, Dicari Pemimpin yang Menjadi Pelayan, Jakarta : Yayasan Komunikasi Bina Kasih, 2002

Franz Magnis Suseno, Etika Dasar;Masalah-Masalah Pokok Filsafat Moral, Yogyakarta: Kanisius, 1987

J. Verkuyl . Etika Kristen, Jakarta : BPK Gunung Mulia

Dr. J.L. Ch. Abeneno, Tafsir Alkitab "Surat Efesus” Vol 1, Jakarta : Momentum, 1997

Robert L. Peterson, Kepemimpinan Agape, Yogyakarta: ANDI, 1995

Ricki Mudjiono dan FX. Dicki P, Kamus Umum Bahasa Indonesia, Jakarta: Scientific Prees, 2008

Peraturan Bersama Menteri Agama dan Menteri Dalam Negeri No: 9 Tahun 2006 dan No: 8 Tahun 2006

Y. B. Mangunwijaya, Pluralitas Agama; Kerukunan dalam Keberagaman, Jakarta : Gramedia, 2001

Wesley Ariarajah, Tak Mungkin Tanpa Sesamaku, Jakarta: BPK Gunung Mulia, 2008

Chandra Suwondo, Sikap Positif, Jakarta, Metanoia, 2005

Gottfried Osei-Mensah, Dicari Pemimpin yang Menjadi Pelayan, Jakarta:Yayasan Komunikasi Bina Kasih, 2002

Mark Atteberry, 10 Hal Terbodah yang Dilakukan Orang Kristen, Jakarta: Gloria Usaha Mulia, 2009

H. Abdul Fatah, Rukun, Jakarta: Pusat Kerukunan UmatBeragama Sekertariat Jenderal Departemen Agama R.I

Natan Setia Budi dan Thresia Kristanty, Bergereja dan Beroikumene di Era Reformasi, Jakarta : Suara GKYE Pedulil Bangsa, 2002

Paul J. Griffths, Kekristenan di Mata Orang Bukan Kristen, Jakarta: BPK Gunung Mulia, 2008

A. N. Wilson, dikutif oleh Nurcholis Mazid, Islam Agama Kemanusiaan: Membangun Tradisi dan Misi Baru Islam Indonesia, Jakarta, Paramadina, 1995

Reyhan Hakim, Sialan Beckham Ternyata Yahudi, Jakarta: Suka Buku, 2009 
Norman Geisler, Who Made God (Siapakah Yang Membuat Allah?), Bandung: Pioner Jaya, 2009

Fred Smith, SR, Memimpin dengan Integritas, Jakarta: Yayasan Pekabaran Injil Immanuel, 2002

S. Wesley Ariarajah, Tak Mungkin Tanpa Sesamaku, Jakarta: BPK Gunung Mulia, 2008

S. Wesley Ariarajah hal. Tak Mungkin Tanpa Sesamaku, Jakarta: BPK Gunung Mulia, 2008

H Schumann, Dialog Antar Umat Beragama, Jakarta: Gunung mulia, 2008

H. M. Zainuddin Daulay, Rukun, Jakarta: Pusat Kerukunan Umat Beragama Sekertariat Jenderal Departemen Agama R.I

Ibrohim dikutip oleh Olaf H Schumann, Dialog Antar Umat Beragama, Jakarta: Gunung Mulia, 2008

http://umum.kompasiana.com/2009/09/12/agama-disuruh-rukun-ya-tidakbisa-tapi-umatnya-bisa/ 